\title{
10 Afterword
}

Author's Note: This work was first drafted in 1992, and touched up only slightly since then. Much has changed since 1992: India, the 'Other' in this treatise is, at least at its major metropolitan cities, far more like America than ever - and Late Modernism has duly wrought its attendant evils. Bollywood apes Hollywood, and New Delhi can feel like New York; and culture, in particular social mores, as alluded to in the opening chapter, is in grave turmoil, and transition. So my sharp contrasts, in that domain, are now overtaken, and appear even naïve, by these remarkable passages. On the autre hand, America is, now, even more America than I painted it, in all regards, and then some. But, powerful forces (which belong to another book) are at work that will see both these contextual situations in these two societies halt, and turnabout. So, to repeat some rather famous words: it is the best of times - and the worst of times.

I was born the meek heir to an aging, ancient civilization that rated, at its noblest, in its sacral scriptures, in all ingenuous humility, peace over prosperity, contemplation over conquest, ahimsa (non-violence) over aggression, and tolerance over tyranny.

These are only values, of course, not necessarily practiced by all, or even by any, in everyday life - but they are ideals that are deeply instilled in the prismatic psyche of India, the most other-worldly, by far, of all the world's great civilizations.

I have drawn my lifeblood, not always knowingly, from such ethereal proprieties; they are my inspiration, my raison d'etre, my daily sustenance, my requital, and recompense. They are what make me - and keep me - Indian, not in a societal, or political sense, but in a quintessentially civilizational, philosophical, denomination; they are also, I hope, what bind me firmly to humanity regardless of caste, clime, or creed. I could belong to no other resume of sensibilities, even were I to change my passport, citizenship, and domicile, every year, for the rest of my life: indeed, I wouldn't wish it otherwise.

By quirk of fate, karma if you will, I took up residence in another great, though young and youthful, bold and brash, hard and hardy, vibrant and vigorous, society: America - the apotheosis of classic European materialism. The clash of the contrast could not have been more extreme, or inevitable, or foredoomed; the irresistible had met the unyielding - reason battled sentiment, instinct warred with intuition. And I slid down the roller-coaster of dire capitulation from Karma to Coca-Cola, from Maya to McDonald's, from Nirvana to the National Inquirer, in almost no time at all.

It may all sound hyperbolic, but the rites of passage were indescribably brutal: beatified by near-blood, sacralized by struggle, and memorialized by total debasement and defeat. Psychologically, and philosophically, a regime of greed, of necessity, offends every sacred value of my aesthetic endowment, sins against every single statute of my discarnate being, revolts against every finer feeling of my sovereign self.

This book is my highly personal ode (and yet, it is still a verifiable cultural anthropology) - in a human society all is ad hominem: it couldn't be otherwise - to that elon- 
gated nightmare of struggle against the premises of the great creed, viewed sometimes from afar, and sometimes from within; but always from the perspective of one who has struggled bitterly for the waning canons of a forgotten civility - and lost. It is small comfort that my personal vanquishment is only a metaphor for the larger defeats of our time, as a hapless world at large lies prostrate today while America Unbound, and run amok, wantonly reshapes it in its own tireless, textured, Technosity (yes, we need such a word): catering to the lower needs, and the lower sensibilities, like no other society in history. Is it Commerce, or Democracy, (or both!) that demands that the very lowest sensibilities must be catered to?

And yet, I know, as a deep intuition, that this is but a pyrrhic victory for the mores of an Amoral Anti-culture: for the Great Redemption, from the sins of materialism, is close at hand, unfolding before our very eyes, even as polar icecaps melt, rainforests vanish, and bees disappear, at one remove: and, at another, canons of civility fail, societal bonds falter, and economies crash. Even in myth and legend (Mayan, Hindu) this is a time of Universal Change (an upswing within Kaliyuga in the Vedic tradition, e.g.).

As such, despite all the foregoing, the best, I am certain, is still, in all transcendence, yet to be. There is a Quantum Revolution now on, anticipated by the remarkable works of Physicists Amit Goswami and John Hagelin, that will lead us all, I feel sure, out of the thralldom of the failed paradigms of yore (and America, one day, much as India, will take a leading role in this burgeoning renaissance): and it was, indeed, an encompassing thralldom that denied us our own humanity, for so very long.

Now I have, relentlessly, criticized materialism as an inhospitable way of life, i.e. as a misguided philosophy in this book: but the new Quantum Physics demonstrates that it is also erroneous Science. My critique, though formulated more than two decades ago, is thereby (quite unexpectedly), at this very late hour, quite fully vindicated. 